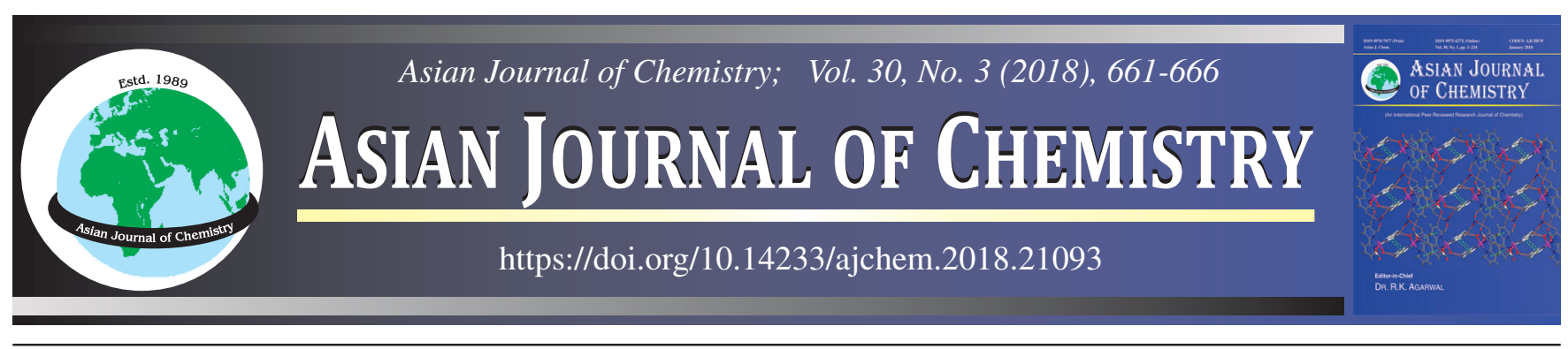

\title{
Synthesis and Biological Activities of New Fused Pyrimidine Compound
}

\author{
Hamid H. Mohammed ${ }^{1, *}$, Zaizafoone N. Nasif ${ }^{1}$, Zainab N. MageEd ${ }^{2}$ and S. Ahmed ${ }^{1}$
}

${ }^{1}$ Department of Chemistry, College of Science, Al-Mustansiryah University, Baghdad, Iraq

${ }^{2}$ Unit of Polymer Research, College of Science, Al-Mustansiryah University, Baghdad, Iraq

*Corresponding author: E-mail: hamidhashim@uomustansiriyah.edu.iq; hammed_sugar@yahoo.com

In this work, a new fused pyrimidine derivatives $\{5$-(4-chlorophenyl)-4-oxo-3,5-dihydro-4H-chromeno[2,3- $d]$ pyrimidin-8-yl formate) $\}$ was prepared from chromene compound \{(2-amino-4-(4-(dimethylamino)phenyl)-5-oxo-4,5-dihydropyran[3,2-c]chromene-3-carbonitrile $\}$ with formic acid in presence of $\mathrm{POCl}_{3}$ and identified by FT-IR and ${ }^{1} \mathrm{H}$ NMR spectra. The pyrimidine compounds have medicinal and biological activities. Therefore the effect of these compounds was studied on human serum acetylthiocholine esterase activity. The results concluded that the greater inhibition percent was found at concentrations $\left(10^{-2}\right) \mathrm{M}$ for each compounds chromene and pyrimidine respectively and indicated that $\mathrm{K}_{\mathrm{m}}$ varied from higher, lesser or the same in the presence of chromene and pyrimidine compared with non-inhibiting system. The maximum and minimum inhibitor concentrations of chromene appeared mix inhibition during enzymatic reaction, in contrast pyrimidine does not compute with substrate on the active site of enzyme (noncompetitive and uncompetitive inhibition). The $\mathrm{V}_{\text {max }}$ value for control sample was higher than in inhibited samples, The biochemical tests revealed that $\mathrm{K}_{\mathrm{i}}$ (the binding affinity of the inhibitor) for chromene and pyrimidine compounds are higher at $10^{-2} \mathrm{M}\left(1.5 \times 10^{-3}, 1.11 \times 10^{-3}\right)$.

Keywords: Pyrimidine, Chromene, Biological activities, Acetyl thiocholine esterase, Inhibitors, Linewer-burk equation.

\section{INTRODUCTION}

Among all heterocyclic compounds, pyrimidines nucleus are one of the most important heterocycles exhibiting remarkable pharmacological activities because it is an essential constituent of all cells and thus of all living matter [1]. Many simple fused pyrimidines such as purines and piperidines are biologically active by themselves or are essential components of important naturally occurring substances (i.e., nucleic acids) [2,3]. The presence of a pyrimidine base in cytosine, uracil and thymine, which are these essential building blocks of nucleicacids (DNA and RNA) is one of the possible reasons for their activities [4]. Condensed pyrimidine derivatives have been reported as antimicrobial [5], analgesic, antiviral, antiinflammatory [6], antiHIV [7], antitubercular [8], antitumor [9], antineoplastic [10], antimalarial [11], diuretic [12], cardiovascular [13] agents and hypnotic drugs for the nervous system [14], calcium- sensing receptor antagonists [15] and also for antagonists of the human A2 A adenosine receptor [16]. In medicinal chemistry pyrimidine derivatives have been well known for their the rapeutic applications. Many pyrimidine derivatives have been developed as chemotherapeutic agents and are widely used.

Pyrimidine ring is found in several vitamins e.g. isoalloxazine, vitamin $\mathrm{B}_{2}$, riboflavin (6,7-dimethyl-9-(D-1-ribityl), thiamine and folic acid [17].
Padmashri et al. [18] reported the synthesis 2-(2',5'-substituted indolideneamino-3'-yl)-4,6-diarylpyrimidines and 2-[2',5'substituted indole-3'-yl)(phenylazo)methyleneimino]-4,6diaryl pyrimidine and screened them for their antimicrobial activity against the Gram-negative bacteria E. coli and Grampositive bacteria.

The aim of this study was to describe the synthesis of new fused pyrimidine derivatives and undertook an exploratory study of their in vitro AChE inhibitory effects. It is believed that this procedure will be helpful in the design of novel $\mathrm{AChE}$ inhibitory compounds.

\section{EXPERIMENTAL}

All reactants and solvents used in this study were reagents grade and they are available from Sigma Aldrich and Fluka companies. Melting points are determined in open capillary tubes in a Germany, Stuarts, SMP30 Melting points apparatus and are uncorrected. Infrared spectra was recorded as $\mathrm{KBr}$ discs using a SHIMADZU FT-IR8400S spectrophotometer. ${ }^{1} \mathrm{H}$ NMR spectra (solvent DMSO- $d_{6}$ ) were recorded on Bruker DMX-500 NMR spectrophotometer $300 \mathrm{MHz}$ spectrometer with TMS as internal standard which were made at chemistry department, Al-Bayt University, Jordan.

Synthesis of 2-amino-4-(4-chlorophenyl)-7-hydroxy$4 H$-chromene-3-carbonitrile (4): To a mixture of $p$-chloro- 
benzaldehyde $(0.14 \mathrm{~g}, 1.0 \mathrm{mmol})$ and malononitrile $(0.07 \mathrm{~g}$, $1 \mathrm{mmol})$ in absolute ethanol (20 mL), few drops of dipropylamine had been added (catalyst) and the reaction mixture was refluxed for $2 \mathrm{~h}$, (TLC control hexane:ethyl acetate, 8:2). The reaction mixture was cooled and poured into ice cold water, the product was filtered, dried and recrystallized from ethanol to give compound $\mathbf{4}$ as a pale yellow solid, (77 \% yield), m.p. 159-161 ${ }^{\circ} \mathrm{C}$, FT-IR (KBr, $\left.v_{\max }, \mathrm{cm}^{-1}\right): 2220(\mathrm{CN}), 2939(\mathrm{CH}$ aliph.), 1595 (C=C).

Synthesis of 2-amino-4-(4-(dimethylamino)phenyl)-5oxo-4,5-dihydropyran[3,2-c]chromene-3-carbonitrile (5): To compound 4, $(0.19 \mathrm{~g}, 1.0 \mathrm{mmol})$ dissolved in ethanol (25 $\mathrm{mL})$ followed a few drops of dipropylamine, then $(0.11 \mathrm{~g}, 1.0$ $\mathrm{mmol}$ ) of resercinol had been added, the reaction mixture was heated under reflux for $4 \mathrm{~h}$, (TLC control, heptane:ethyl acetate, $8: 2$ ). The reaction mixture was cooled and poured onto ice cold water, the product was filtered, dried and recrystallized from ethanol to give compound $\mathbf{5}$ as an yellow solid, (85\% yield), m.p. $228-230{ }^{\circ} \mathrm{C}$, FT-IR $\left(\mathrm{KBr}, v_{\max }, \mathrm{cm}^{-1}\right): 3460(\mathrm{OH}), 3338$, $33246\left(\mathrm{NH}_{2}\right), 2191(\mathrm{CN}), 1641(\mathrm{C}=\mathrm{C}) .{ }^{1} \mathrm{H} \mathrm{NMR}, \delta=4.74 \mathrm{ppm}$ [s, $1 \mathrm{H}, \mathrm{CH}], \delta=6.19-7.79 \mathrm{ppm}\left[\mathrm{m}, 10 \mathrm{H}, \mathrm{Ar}-\mathrm{H}, \mathrm{OH}\right.$ and $\left.\mathrm{NH}_{2}\right]$.

Synthesis of 5-(4-chlorophenyl)-4-oxo-3,5-dihydro-4Hchromeno[2,3- $d$ ] pyrimidin-8-yl formate (6): To $(0.29 \mathrm{~g}, 1.0$ $\mathrm{mmol})$ of compound $\mathbf{5}, 3 \mathrm{~mL}$, formic acid $(1.0 \mathrm{mmol}) \mathrm{had}$ been added as solvent, then $\mathrm{POCl}_{3}(0.2 \mathrm{~mL})$ was added quickly. The mixture was refluxed for $4 \mathrm{~h}$, (TLC control hexane:ethyl acetate, $6: 4)$. The mixture was cooled and followed by adding $50 \mathrm{~mL}$ ice water. A mass of white precipitate was produced. $\mathrm{K}_{2} \mathrm{CO}_{3}$ was added to neutralize the acid till no bubble occurs. The reaction mixture was filtered and washed with a small amount of ethanol, dried to give compound $\mathbf{6}$, pale yellow solid, $\left(60 \%\right.$ yield), m.p. $210-213{ }^{\circ} \mathrm{C}$, FT-IR $\left(\mathrm{KBr}, v_{\max }, \mathrm{cm}^{-1}\right)$ : $3442(\mathrm{NH}), 1765(\mathrm{OCOH}), 1631(\mathrm{C}=\mathrm{O}$ amid $), 1641(\mathrm{C}=\mathrm{C}) .{ }^{1} \mathrm{H}$ NMR, $\delta=4.85 \mathrm{ppm}[\mathrm{s}, 1 \mathrm{H}, \mathrm{CH}], \delta=6.17-7.84 \mathrm{ppm}[\mathrm{m}, 9 \mathrm{H}$, $\mathrm{Ar}-\mathrm{H}, \mathrm{N}=\mathrm{CH}$ and $\mathrm{NH}], \delta=9.75 \mathrm{ppm}[\mathrm{s}, 1 \mathrm{H}, \mathrm{OCOH}]$.

Determination of AChE activity: Human serum AChE activity was determined using Ellman et al. [19] method as follows: $(50 \mu \mathrm{L})$ of DTNB solution $(0.001 \mathrm{M})$ is added to $(2.25$ $\mathrm{mL}$ ) of sodium phosphate buffer solution $(\mathrm{pH}=7.3,0.2 \mathrm{M})$, then added $(10 \mu \mathrm{L})$ of serum, mixed well and $2 \mathrm{~mL}$ of the mixture is transferred to a measuring cell $(1 \mathrm{~cm})$ after that $34 \mu \mathrm{L}$ of acetyl thiocholineiodide (ASChI, $0.06 \mathrm{M}$ ) is added. The changes in absorbency are measured before and after adding the substrate at $430 \mathrm{~nm}$ for $2 \mathrm{~min}$. The enzyme activity is calculated as concentration in $\mu \mathrm{mol}$ of the substrate hydrolyzed to each $\mathrm{mL}$ of samples in $2 \mathrm{~min}$ and expressed as $(\mu \mathrm{mol} / 2$ $\min / \mathrm{mL}$ ).

Determination of biological activity of chromene and pyrimidine derivatives $(\mathbf{5 , 6})$ : A stock concentration solution $(0.01 \mathrm{M})$ of each target derivatives $(\mathbf{5 , 6})$ has been prepared and then different concentrations $\left(10^{-2}, 10^{-3}, 10^{-5}, 10^{-7}, 10^{-9}\right.$ and $10^{-11} \mathrm{M}$ ) of each compound were prepared by diluting it with dimethyl sulfoxide (DMSO) as solvent. AChE activity is measured in human serum as follows: $(50 \mu \mathrm{L})$ of DTNB solution $(0.001 \mathrm{M})$ was added to $(2.25 \mathrm{~mL})$ of sodium phosphate buffer solution $(\mathrm{pH}=7.3,0.2 \mathrm{M}), 0.25 \mathrm{~mL}$ of inhibitor was mixed with $2 \mathrm{~mL}$ of the same buffer, then $(10 \mu \mathrm{L})$ of serum was added, mixed well and $(2 \mathrm{~mL})$ of the mixture was transferred to a measuring cell $(1 \mathrm{~cm})$, then $(34 \mu \mathrm{L})$ of $(\mathrm{AChI} 0.06 \mathrm{M})$ was added, the changes in absorbency was measured after adding the substrate at $430 \mathrm{~nm}$ for $3 \mathrm{~min}$. The inhibition percentage was calculated by comparing the activity between with and without inhibitor under the same conditions according to the equation:

$$
\text { Inhibition }(\%)=\frac{\text { Activity in presence of inhibitor }}{\text { Activity in absence of inhibitor }} \times 100
$$

Determination the type of inhibition [20]: Constant concentrations of inhibitors (higher and lower) were being used with different concentrations of substrate $(0.02,0.04,0.06$ and $0.08 \mathrm{M}$ ) to study the type of inhibition. These concentrations were prepared using the stock solution $(0.1 \mathrm{M})$ of AChI. The enzyme activity was determined with and without the inhibitors using the linewer-burkequation by ploting $1 / \mathrm{V} v s .1 /[\mathrm{s}]$ following values were then calculated as follows: 1) Ki, 2) Apparent $\mathrm{V}_{\text {max }}\left(\mathrm{V}_{\text {mapp }}\right)$, 3) Apparent $\mathrm{K}_{\mathrm{m}}\left(\mathrm{K}_{\text {mapp }}\right)$, 4) type of inhibition.

\section{RESULTS AND DISCUSSION}

The present study focused on the synthesis of 2-amino-4(4-chlorophenyl)-7-hydroxy-4H-chromene-3-carbonitrile (4) via reaction of molononitrile with $p$-chlorobenzaldehyde to produced (4-chlorobenzylidene)malononitrile, which upon condensation with resorcinol in presence of dipropylamine gave 2-amino-4-(4-chlorophenyl)-7-hydroxy-4H-chromene-3carbonitrile (4) (Scheme-I). These results are similar to the results reported in literatures [21,22]. The FT-IR spectrum of compound 4 shows $v(C \equiv N)$ stretching band at $2220 \mathrm{~cm}^{-1}$,

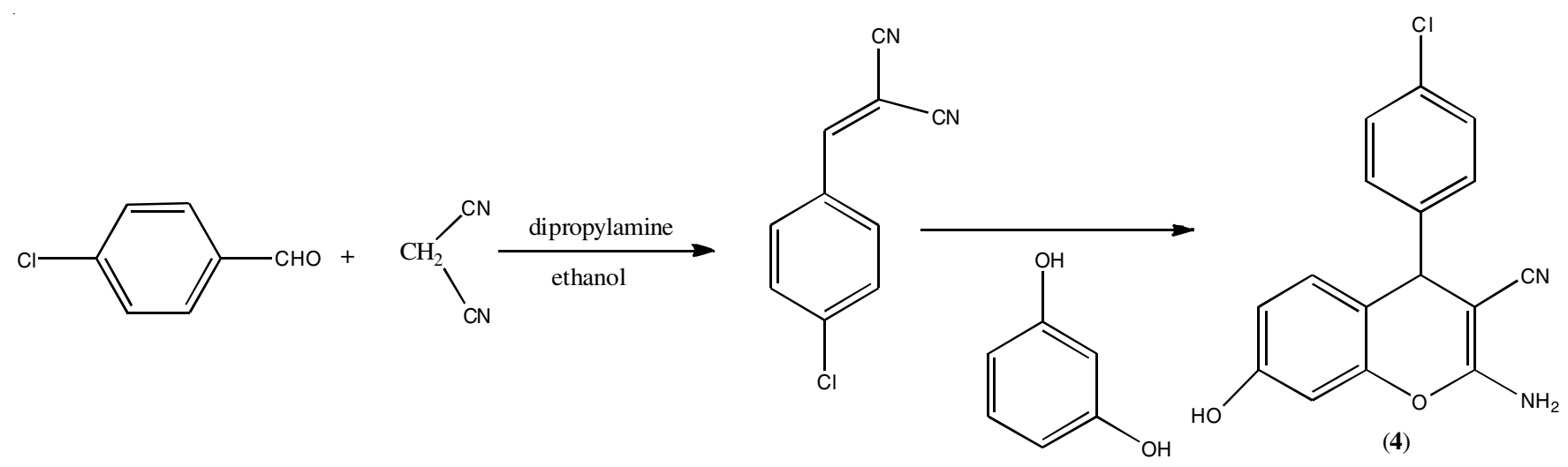

Scheme-I 
$v(\mathrm{C}=\mathrm{C})$ stretching band at $1595 \mathrm{~cm}^{-1}$ and $\mathrm{v}(\mathrm{C}-\mathrm{H})$ aliphatic stretching band at $2939 \mathrm{~cm}^{-1}$. The FT-IR spectrum of compound 5 shows $v(\mathrm{OH})$ stretching bands at $3460 \mathrm{~cm}^{-1}, v\left(\mathrm{NH}_{2}\right)$ stretching bands at 3338 and $3324 \mathrm{~cm}^{-1}$ and $v(\mathrm{C} \equiv \mathrm{N})$ stretching band at $2191 \mathrm{~cm}^{-1}$ and $v(\mathrm{C}=\mathrm{C})$ stretching band at $1614 \mathrm{~cm}^{-1}$. The ${ }^{1} \mathrm{H}$ NMR spectrum shows singlet signal at $\delta=4.74 \mathrm{ppm}$ for $\mathrm{CH}$ of pyrone cycle and multi-signal at $\delta=6.19-7.79 \mathrm{ppm}$ for Ar$\mathrm{H}, \mathrm{OH}$ and $\mathrm{NH}_{2}$.

Preparation and characterization of compound 6: The synthetic reactions are summarized in Scheme-II.<smiles>N#CC1=C(N)Oc2cc(O)ccc2C1c1ccc(Cl)cc1</smiles>

(4)<smiles>CC(C)(C)OC(=O)c1ccc2c(c1)Oc1nc[nH]c(=O)c1C2c1ccc(Cl)cc1</smiles>

(6)
Scheme-II

The importance of biological activities of pyrimidinone derivative (6) has resulted in the development of several synthetic methods $[23,24]$, where these method suffers from several disadvantages such as vigorous conditions, long reaction times and low yields $[25,26]$.

In present work, reaction system $\mathrm{POCl}_{3}$ acted not only as a chlorinating reagent, but also an oxidant. The compound 4 was first oxidized to give the corresponding $\mathrm{N}$-substituted 5-amino-pyrazole-4-carboxamide, which immediately reacted with the acyl chloride which might be generated in situ from the reaction of the carboxylic acid with $\mathrm{POCl}_{3}$, followed by cyclization and condensation of the intermediate. The reaction went smoothly by controlling the amount of $\mathrm{POCl}_{3}$ and the obtained product gave a good yield. These results are similar to the results obtained in literatures [27,28].

The FT-IR spectra of compound $\mathbf{6}$, shows $v(\mathrm{NH})$ stretching band at $3442 \mathrm{~cm}^{-1}$ and disappearance $v\left(\mathrm{NH}_{2}\right)$ and $v(\mathrm{C} \equiv \mathrm{N})$ stretching bands at $3338,3324 \mathrm{~cm}^{-1}$ and 2191 , respectively, also disappearance $v(\mathrm{OH})$ stretching bands at $3460 \mathrm{~cm}^{-1}$. Appearance of $v(\mathrm{NH})$ stretching band at $3442 \mathrm{~cm}^{-1}$, stretching bands at $1765 \mathrm{~cm}^{-1}$ for $\mathrm{v}(\mathrm{OCOH})$ and $1631 \mathrm{~cm}^{-1}$ for $\mathrm{v}(\mathrm{C}=\mathrm{O}$ amide $)$ is observed. The ${ }^{1} \mathrm{H}$ NMR spectrum of compound $\mathbf{6}$ shows singlet signal at $\delta=4.85 \mathrm{ppm}$ for $(\mathrm{CH})$, multi-signals at $\delta=6.17-7.84$ ppm for $(\mathrm{NH}), \mathrm{N}=\mathrm{CH}$ and $\mathrm{Ar}-\mathrm{H}$.

Biological activity: Acetylcholine can be hydrolyzed by choline esterase 1 and acetylcholine esterase1. Measurements of choline esterase activity are clinically important in case of suspicion of toxicity with organophosphate pesticides and heritable deficiency of the enzyme with risk of prolonged apnea following an aesthesia with the muscle relaxant succinylb is choline (suxamethonium) [29]. Present work determined the activity of human $\mathrm{AChE}$ in the absence and presence of chromene and pyrimidine under different substrate concentrations and designed to investigate the biological activity of two compounds $\mathbf{4}$ and $\mathbf{6}$.
The effect of solvent DMSO did not show any inhibitory effect. Before each set of inhibition experiments were conducted, the AChE activity was measured (Fig. 1) for four different concentrations of acetylthiocholineiodide (substrate) $(0.02$, 0.04, 0.06 and 0.08) M.

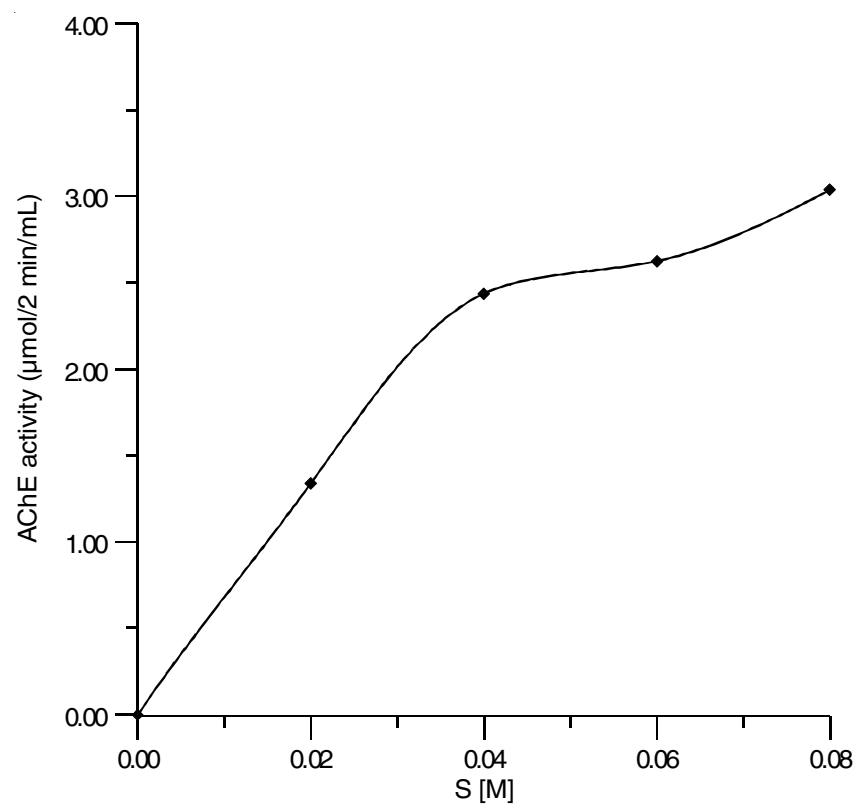

Fig. 1. Michaelis-Menten plot of AChE at different concentrations of substrate and without inhibitor

The effect of different concentrations of each inhibitor at acetylcholine concentrations on AChE activity is illustrated in Fig. 2. The biochemical tests indicated that chromene and pyrimidine compounds have caused noticed inhibitory effects on enzyme activity compared with the measured normal values of enzyme activity $2.75 \mu \mathrm{mol} / 2 \mathrm{~min} / \mathrm{mL}$ (Table-1).

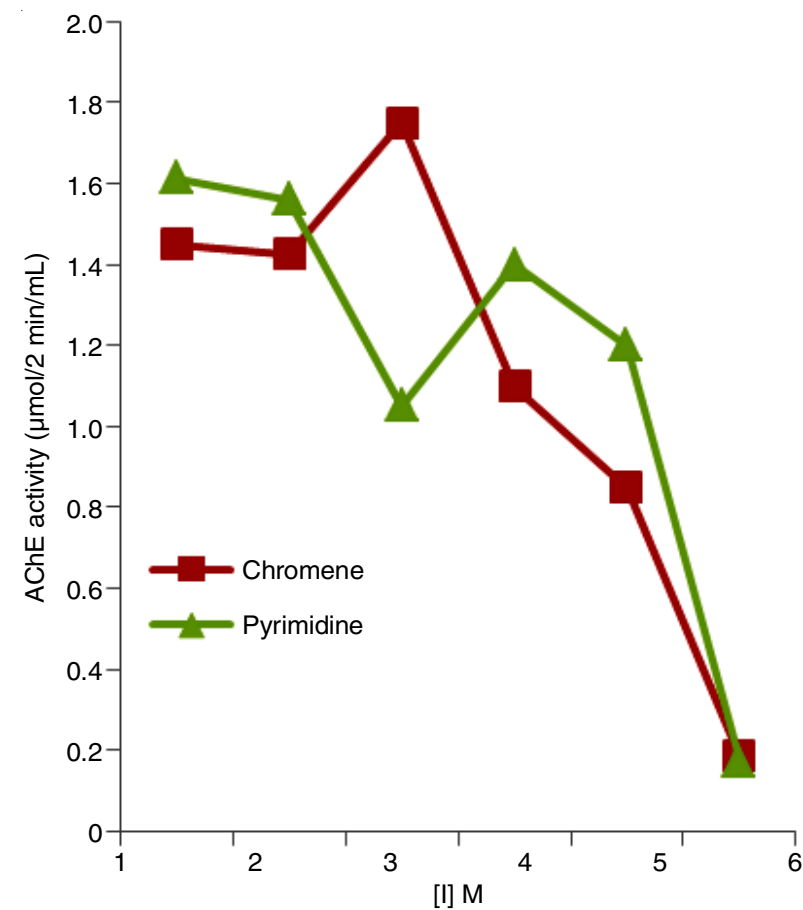

Fig. 2. Effect of different chromene (5) and pyrimidine (6) concentrations $\left(10^{-2}, 10^{-3}, 10^{-5}, 10^{-7}, 10^{-9}, 10^{-11)} \mathrm{M}\right.$ on AChE activity 
Table- 1 showed that the greater inhibition percent was found at concentrations $\left(10^{-2}\right) \mathrm{M}$ for each compounds chromene and pyrimidine respectively, these can be attributed to the presence of more than one nucleophile sides in two compounds (hydroxyl, carbonitrite, chlorophenyl, amino) groups which may led to good orient to active site of the enzyme. The significant inhibition was found at concentration $\left(10^{-2} \mathrm{M}\right)$ in each compound.

\begin{tabular}{cccc}
\multicolumn{4}{c}{ TABLE-1 } \\
EFFECT OF DIFFERENT CONCENTRATIONS OF \\
CHROMENE AND PYRMIDINE COMPOUNDS ON \\
THE HUMAN SERUM AChE ACTIVITY \\
\hline & Inhibition & AChE activity & Inhibition $(\%)$ \\
\hline conc. $(\mathrm{M})$ & $(\mu \mathrm{mol} / 2 \mathrm{~min} / \mathrm{mL})$ & - \\
\hline & Zero & 2.750 & $93.20^{*}$ \\
& $10^{-2}$ & 0.187 & 69.10 \\
Compound 4 & $10^{-3}$ & 0.850 & 60.00 \\
& $10^{-5}$ & 1.100 & 36.64 \\
& $10^{-7}$ & 1.750 & 48.19 \\
& $10^{-9}$ & 1.425 & 47.28 \\
\hline & $10^{-11}$ & 1.450 & $93.64 *$ \\
& $10^{-2}$ & 0.175 & 56.36 \\
Compound 6 & $10^{-3}$ & 1.200 & 49.10 \\
& $10^{-5}$ & 1.400 & 61.82 \\
& $10^{-7}$ & 1.050 & 43.28 \\
& $10^{-9}$ & 1.560 & 41.39 \\
\hline *Maximum inhibition concentration in each compound.
\end{tabular}

Type of inhibition: In this study, the type of inhibition and kinetic parameters $\left(\mathrm{K}_{\mathrm{m}}, \mathrm{V}_{\max }\right.$ and $\left.\mathrm{K}_{\mathrm{i}}\right)$ at different concentrations of substrate is determined and under the same conditions by using Linweaver-Burk equation. The study indicated that $\mathrm{K}_{\mathrm{m}}$ varied from higher, lesser or the same in the presence of chromene and pyrimidine compared with non-inhibition system (Fig. 3). A high $\mathrm{K}_{\mathrm{m}}$ means the lesser affinity of substrate toward enzyme and the higher inhibitor affinity to fits very well into the active-site of the enzyme which presence in both maximum and minimum inhibitor concentrations of chromene (mix inhibition). In contrast pyrimidine does not compute with substrate on the active site of enzyme (non-competitive and uncompetitive inhibition). The affinity is obviously influenced by several factors, e.g., size, three-dimensional structure, presence of groups which easily bind non-covalently to groups in or close to the active site, etc.

A consequence of such a good fit could be attributed to the orientation in space such that the covalent or hydrogen bonding to the serine residue. The $\mathrm{V}_{\max }$ value for control sample was higher than in inhibited samples, so it is clear that the amount of active enzyme $V_{\max }$ present in non-inhibiting system.

The biochemical tests revealed that $\mathrm{K}_{\mathrm{i}}$ (binding affinity of the inhibitor) for chromene and pyrimidine compounds are higher at $10^{-2} \mathrm{M}$ as clear in Table-2 $\left(1.5 \times 10^{-3}, 1.11 \times 10^{-3}\right)$. Table-1 showed the inhibition percent of $10^{-2}$ were greater $(93.2$ and 93.34) \% for chromene and pyrimidine, respectively. The difference in $\mathrm{K}_{\mathrm{i}}$ values enables to conclude that not all of the assumptions underlying classic Michaelis-Menten equations are being obeyed and that the data are consistent with the kinetics of a tight-binding inhibitor. Also, the results demonstrated that chromene and pyrimidine exhibit different types of inhibition at maximum own concentration. The mixed inhibition by chromene can explain in order to inhibitors structure that make a conformational changes after binding to $-\mathrm{SH}$, $-\mathrm{COOH}$, imidazole group of Ser, His, Glu in AChE, which are either localized in the active center or are important in determining the active conformation of enzyme molecule. On the other hand, non and uncompetitive inhibition of pyrimidine can be explain according to the classical models described that the inhibitor bind to another site that cause conformational change lock the enzyme and prevent the substrate binding or decreasing substrate affinity to $\mathrm{AChE}$.

\section{REFERENCES}

1. T. Sasada, F. Kobayashi, N. Sakai and T. Konakahara, Org. Lett., 11, 2161 (2009); https://doi.org/10.1021/o1900382j.

2. R.F. Lloyd, C.G. Skinner and W. Shive, Can. J. Chem., 45, 2213 (1967); https://doi.org/10.1139/v67-357.

3. V.P. Litvinov, ed.: A.R. Katritzky, The Chemistry of Thienopyrimidines, In: Advances in Heterocyclic Chemistry, Elsevier, vol. 92, p. 83-126 (2006).

4. M. Amir, S.A. Javed and H. Kumar, Indian J. Pharm. Sci., 69, 337 (2007); https://doi.org/10.4103/0250-474X.34540.

5. R.B. Patel, P.S. Desai, K.R. Desai and K. Chikhalia, Indian J. Chem., 45B, 773 (2006).

6. A.E.-Galil E. Amr, N.M. Sabry and M.M. Abdulla, Monatsh. Chem., 138, 699 (2007);

https://doi.org/10.1007/s00706-007-0651-0.

7. N. Fujiwara, T. Nakajima, Y. Ueda, H. Fujita and H. Kawakami, Bioorg. Med. Chem., 16, 9804 (2008);

https://doi.org/10.1016/j.bmc.2008.09.059.

8. L. Ballell, R.A. Field, G.A.C. Chung and R.J. Young, Bioorg. Med. Chem. Lett., 17, 1736 (2007); https://doi.org/10.1016/j.bmcl.2006.12.066.

9. E. Wagner, K. Al-Kadasi, M. Zimecki and W. Sawka-Dobrowolska, Eur. J. Med. Chem., 43, 2498 (2008); https://doi.org/10.1016/j.ejmech.2008.01.035.

10. C. Jean-Damien, B. David, K. Ronald, G. Julian, L. Pan and D. Robert, PCT Int. Appl., 22,608 (2002).

11. K. Gorlitzer, S. Herbig and R.D. Walter, Pharmazie, 52, 670 (1997).

12. I.V. Ukrainets, I.A. Tugaibei, N.L. Bereznykova, V.N. Karvechenko and A.V. Turov, Chem. Heterocycl. Comp., 5, 718 (2008); https://doi.org/10.1007/s10593-008-0076-7.

13. M. Kurono, M. Hayashi, K. Miura, Y. Isogawa and K. Sawai, Japanese Kokai Tokkyo Koho, 62-267, 272 (1987); Chem. Abstr., 109, 37832 (1988).

14. S.Q. Wang, L. Fang, X.J. Liu and K. Zhao, Chin. Chem. Lett., 15, 885 (2004).

TABLE-2

KINETIC PROPERTIES OF AChE WITH AND WITHOUT CHROMENE AND PYRIMIDINE COMPOUNDS

\begin{tabular}{|c|c|c|c|c|c|}
\hline Sample & Inhibitor conc. (M) & $\mathrm{K}_{\mathrm{m}}(\mathrm{M})$ & $\mathrm{V}_{\max }(\mu \mathrm{mol} / \mathrm{mL} / \mathrm{min})$ & $\mathrm{K}_{\mathrm{i}}(\mathrm{M})$ & Inhibition type \\
\hline Control & Zero & 0.050 & 5.00 & - & - \\
\hline \multirow[t]{2}{*}{ Compound 4} & $10^{-3}$ & 0.070 & 2.00 & $1.50 \times 10^{-3}$ & Mix \\
\hline & $10^{-7}$ & 0.125 & 3.33 & $3.63 \times 10^{-8}$ & Mix \\
\hline \multirow[t]{2}{*}{ Compound 6} & $10^{-2}$ & 0.050 & 0.50 & $1.11 \times 10^{-3}$ & Non-competitive \\
\hline & $10^{-7}$ & 0.038 & 2.85 & $1.32 \times 10^{-11}$ & Uncompetitive \\
\hline
\end{tabular}




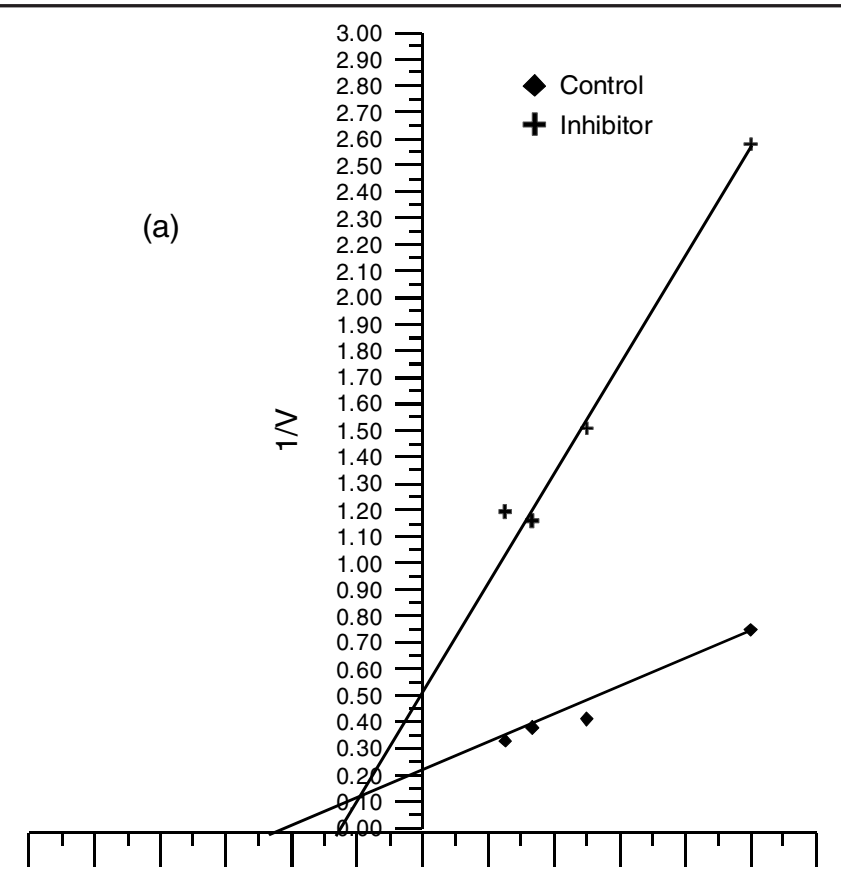

-60.00-50.00-40.00-30.00-20.00-10.00 0.00 10.0020.0030.00 40.00 50.0060.00 $1 / \mathrm{S}$

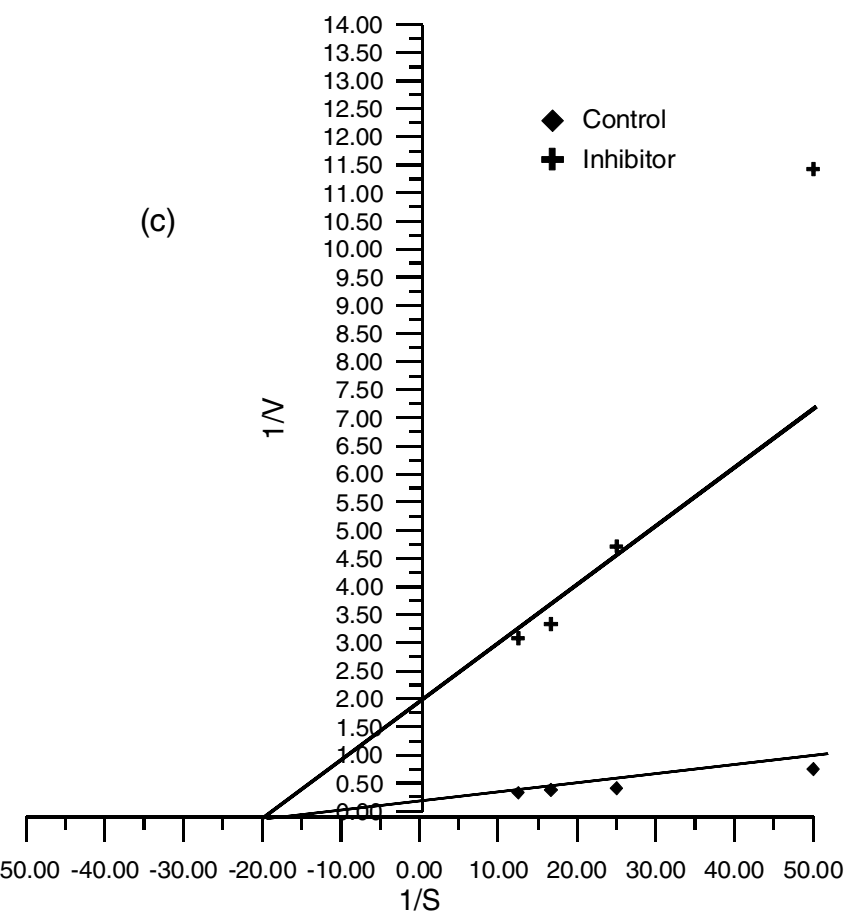

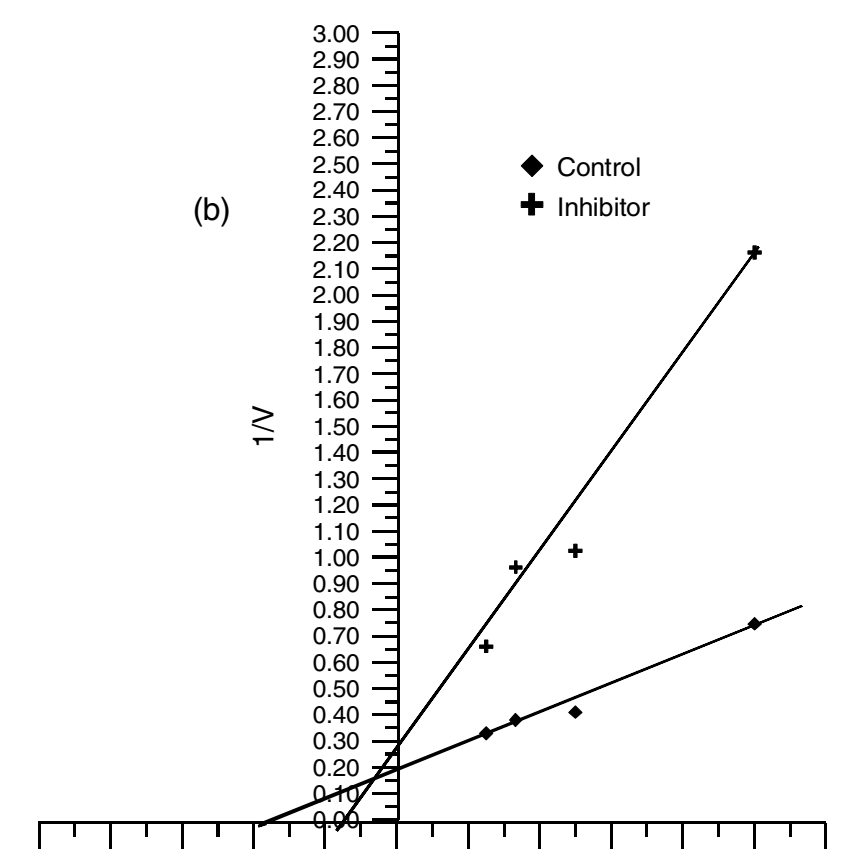

$-50.00-40.00-30.00-20.00-10.000 .0010 .0020 .0030 .0040 .0050 .0060 .00$ $1 / \mathrm{S}$

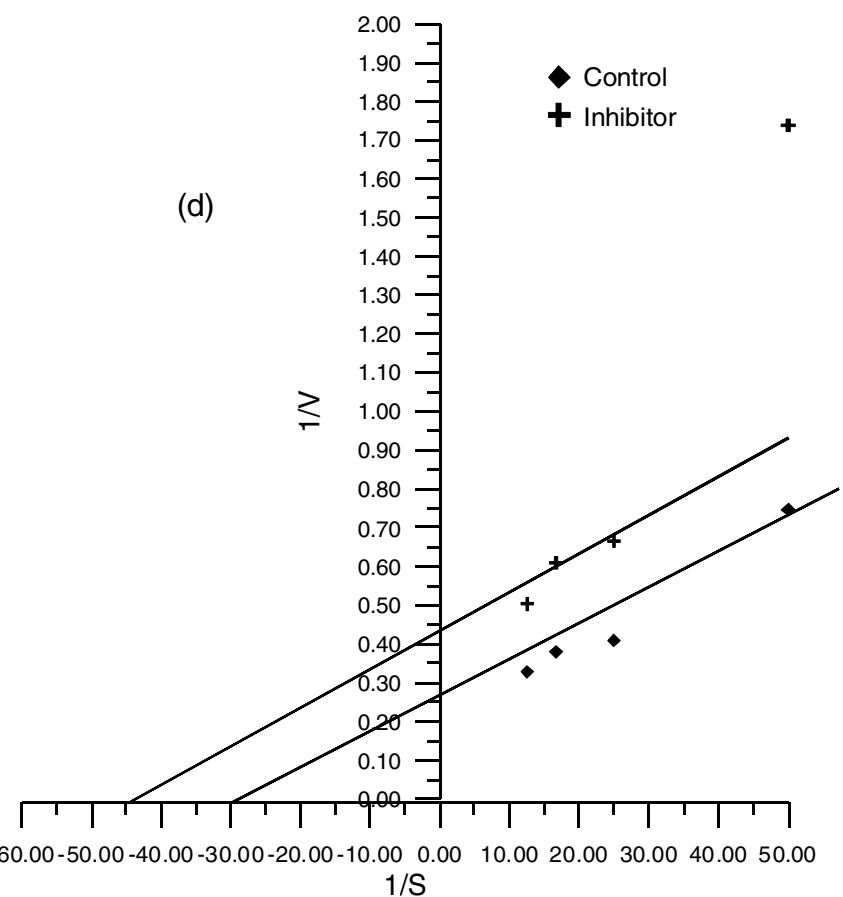

Fig. 3. Lineweaver-Burk Plots of AChE in presence of maximum and Minimuminhibitor concentrations of compounds $\mathbf{4}$ and $\mathbf{6}$ which selected (a) minimum inhibitor concentrations of compound 4; (b) maximum inhibitor concentrations of compound 4; (c) minimum inhibitor concentrations of compound $\mathbf{6}$; (d) maximum inhibitor concentrations of compound $\mathbf{6}$

15. W. Yang, Z. Ruan, Y. Wang, K. Van Kirk, Z. Ma, B.J. Arey, C.B. Cooper, R. Seethala, J.H.M. Feyen and J.K. Dickson, J. Med. Chem., 52, 1204 (2009); https://doi.org/10.1021/jm801178c.

16. R.J. Gillespie, S.J. Bamford, R. Botting, M. Comer, S. Denny, S. Gaur, M. Griffin, A.M. Jordan, A.R. Knight, J. Lerpiniere, S. Leonardi, S. Lightowler, S. McAteer, A. Merrett, A. Misra, A. Padfield, M. Reece, M. Saadi, D.L. Selwood, G.C. Stratton, D. Surry, R. Todd, X. Tong, V. Ruston, R. Upton and S.M. Weiss, J. Med. Chem., 52, 33 (2009); https://doi.org/10.1021/jm800961g.

17. O. Stanisaw, Jordan J. Chem., 4, 1 (2009).

18. B. Padamshari, V.P. Vaidya and M.L. Vijayayakumar, Indian J. Heterocycl. Chem., 12, 89 (2002).
19. G.L. Ellman, K.P. Courtney, V. Andres Jr. and R.M.F. Stone, Biochem. Pharmacol., 7, 88 (1961); https://doi.org/10.1016/0006-2952(61)90145-9.

20. N. Zaizafoon, Int. J. Biochem. Res. Rev., 7, 100 (2015); https://doi.org/10.9734/IJBCRR/2015/15784.

21. S. Tu, H. Jiang, F. Fang, Y. Feng, S. Zhu, T. Li, X. Zhang and D. Shi, J. Chem. Res., 396 (2004); https://doi.org/10.3184/0308234041423781.

22. R. Medyouni, N. Hamdi, R.B. Said, A.S. Al-Ayed and F. Zagrouba1, J. Chem., Article ID 47265 (2012); https://doi.org/10.1155/2013/472657. 
23. M.X.W. Jiang, N.C. Warshakoon and M.J. Miller, J. Org. Chem., 70, 2824 (2005); https://doi.org/10.1021/jo0484070.

24. J.A. Markwalder, M.R. Arnone, P.A. Benfield, M. Boisclair, G.R. Burton, C.H. Chang, S.S. Cox, P.M. Czerniak, C.L. Dean, D. Doleniak, R. Grafstrom, B.A. Harrison, R.F. Kaltenbach, D.A. Nugiel, K.A. Rossi, S.R. Sherk, L.M. Sisk, P. Stouten, G.L. Trainor, P. Worland and S.P. Seitz, J. Med. Chem., 47, 5894 (2004); https://doi.org/10.1021/jm020455u.

25. S. Schenone, O. Bruno, M. Radi and M. Botta, Mini Rev. Org. Chem., 6, 220 (2009); https://doi.org/10.2174/157019309788922739.
26. R.K. Hemender, R.A. Panduranga, V. Veeranagaiah and N. Versatile, Indian J. Chem., 31B, 163 (1992).

27. X. Zhang, Q. Lin and P. Zhong, Molecules, 15, 3079 (2010); https://doi.org/10.3390/molecules 15053079.

28. N.A. Al-Masoudi, H.H. Mohammed, A.M. Hamdy, O.A. Akrawi, N. Eleya, A. Spannenberg, C. Pannecouque and P. Langer, Z. Naturforsch, $68 \mathbf{b}$, 229 (2013).

29. S.S. Brown, W. Kalow, W. Pilz, M. Whittaker and C.L. Woronic, Adv. Clin. Chem., 22, 1 (1981); https://doi.org/10.1016/S0065-2423(08)60046-3. 